\title{
Erratum to: Acid mine drainage: electrochemical approaches to prevention and remediation of acidity and toxic metals
}

\author{
Dorin Bejan $^{1}$ - Nigel J. Bunce ${ }^{1}$
}

Published online: 22 January 2016

(C) Springer Science+Business Media Dordrecht 2016

Erratum to: J Appl Electrochem (2015)

45:1239-1254

\section{DOI 10.1007/s10800-015-0884-2}

The article has been published with the incorrect category "Research Article". However, the correct category is "Review paper".

The online version of the original article can be found under doi: 10.1007/s10800-015-0884-2.

\section{Nigel J. Bunce}

nbunce@uoguelph.ca

1 Department of Chemistry, Electrochemical Technology

Centre, University of Guelph, Guelph N1G 2W1, Canada 